\title{
Tudásmenedzsment az egészségügyi közigazgatásban: egy tudástár felépítésének tapasztalatai
}

\author{
Knowledge management in health administration: \\ experiences in establishing knowledge repository
}

\section{Merész Gergő \\ Országos Gyógyszerészeti és Élelmezés-egészségügyi Intézet, Technológia-értékelő Főosztály}

A közigazgatás eredménytermékeivel kapcsolatos magas minőségi elvárásoknak való megfeleléshez és az ehhez szükséges eröforrások biztosításához újszerü eszközökre van szükség a tudásmenedzsmentben. Jelen közleményben egy olyan tudástár (repozitórium) felépítésének leírását mutatjuk be, ami a technológia-értékelési szakvélemények elkészítését támogatja, és emellett számos szervezeti célkitüzés elérését is szolgálja.

The expectations in terms of quality towards the deliverables of public administration processes and maintaining the resources to meet these expectations imply the need for novel tools for knowledge management. This paper describes the experience gained by establishing a knowledge repository, which supports compiling health technology assessment reports while also contributing to the achievement of some organisational goals.

\section{BEVEZETÉS ÉS CÉLKITŰZÉS}

A közigazgatásban végzett munkához szükséges ismeretanyag és az ahhoz kapcsolódó információk forrásai sokfélék lehetnek. A legalapvetőbb információforrás a formális képzések keretében szerzett ismeretanyag, mellyel az újonnan felvett munkatársak rendelkeznek, és erről leendő munkahelyi vezetője a felvételi folyamatban megbizonyosodhatott. Ugyanakkor ez az ismeretanyag részleteiben különbséget mutathat. Akár a konkrét képzési helytől függően, akár időben is finomodhat, illetve annak bizonyos részei egyes munkakörökben alig, míg másokban kiemelkedően relevánsak lesznek. A szakmai ismeretanyag alkalmazását a közigazgatási munkavégzés során különféle jogszabályok, utasítások, adatbázisokból származó információk egészítik ki. Ezek széles körben hozzáférhető, formális tudásanyagnak tekinthetők, de időről időre megváltoznak, frissülnek. Végül pedig ismeretanyagként kell tekinteni a tapasztalatszerzés révén kialakuló jó gyakorlatokra, szokásokra, tapasztalatokra, melynek lehet formális (például standard operating procedure - SOP) és informális (például munkahelyi megbeszélésen elhangzott kijelentés, közvetlen szóbeli utasítás) komponense.

A szerteágazó ismeretanyag mellett egy szervezet személyi állománya is folyamatosan változhat. A jelenség minden szervezetben jelen van, de nem egyformán érinti a szervezeti egységeket, illetve a szervezeti egységen belüli beosz- tásokat. Egy-egy tapasztalt munkatárs vagy éppen a szakmai vezető távozása a szervezeti egységben nemcsak a rendelkezésre álló szakértői kapacitásokat redukálhatja, hanem az informális ismeretanyag („ezt így szoktuk csinálni”), esetleg a közösségi tudás („ezt ő szokta tudni”) visszaszorulását is előidézheti. Korábbi, az egyes munkakörökhöz jól illeszkedő képzések megszűnésével és újak létrejöttével a szervezet állományához csatlakozó munkatársak ismeretanyaga is változhat. A képzések kimeneteli követelményei nem maradéktalanul illeszkednek a munkaköri leírásokhoz, illetve az erős munkaerőpiaci kereslet kikényszerítheti a korábban megszokottól eltérő végzettséggel rendelkező munkatárs felvételét. Ugyanakkor az eredménytermékekkel kapcsolatos elvárások nem differenciáltak a munkakörben dolgozók végzettsége szerint.

A fenti kihívásokkal való szembenézés mellett alapvető adófizetői elvárás egy közösségi erőforrásokat felhasználó szervezet felé, hogy a rendelkezésére álló erőforrásokkal az elvárható legnagyobb körültekintéssel bánjon. Ez magában foglalja azt is, hogy a szakemberek javadalmazása mellett a különféle képzésekre, betanításra felhasználható erőforrások nem korlátlanul állnak rendelkezésre. Ez alatt nemcsak a képzési díjakat érdemes érteni, hanem a képzés transzferköltségeit is, azaz a betanítást végző munkatárs erőfeszítéseit, vagy akár a betanításhoz használt szoftveres felület, információforrás üzemeltetési költségeit és licenszdíjait is.

Összefoglalóan tehát a fejlesztési igényt a közigazgatási eredménytermékekkel kapcsolatos magas minőségi elvárások, illetve az ehhez szükséges erőforrások egyensúlyát fenyegető különböző eredőjű kockázatok szülték. A problémafelvetés sokrétűsége okán az erre adható válasz sem triviális, annak összetettnek kell lennie. A fent bemutatott jelenségekre részmegoldást kínálhatnak az SOP-k, esetleg folyamatellenőrzési nyomvonalak, ugyanakkor ezek napi gyakorlatban történő hasznosíthatósága, vagy éppen a teljes szervezeti egység esetén értelmezhető támogató funkciójuk kiteljesedése kérdéses lehet. A kézirat célja, hogy bemutassa a problémafelvetésre adható válaszként kialakított repozitórium, azaz egy tudástár felépítése során szerzett tapasztalatokat.

\section{MEGVALÓSíTÁS}

A megfelelő szintű munkavégzéshez szükséges tudásanyag megszerzésének lépései egyéni szinten elviekben nem különösebben összetettek, legfőképpen a szakmai anyagok tanulmányozásából és a tapasztaltabb munkatársak 
ismereteinek elsajátításából állnak. A tudást közvetítő felületek között megjelenő online repozitórium, vagyis egy dokumentumszerver-szerű online szolgáltatás segítheti azt, hogy a szakmai anyagok egy adott forrásból megismerhetőek legyenek, illetve ahol az újra és újra átadott ismeretek kiegészíthetők, rendszerezhetők is egyben.

A közigazgatási munkához szükséges ismeretanyag elsajátítására kínálhat megoldást egy tudástárként jellemezhető dokumentumszerver, ha a formális képzés keretében szerzett ismeretanyag adaptálására (a releváns szakaszok részletes bemutatása, források kapcsolása), tartalomgyártásra biztosít lehetőséget a szerkeszhető aloldalaival, amelyeken nem csak szövegszerü, hanem multimédiás vagy külön fájlként letölthető tartalom is elhelyezhető. Az indexált tartalom kereshetősége révén ezek elérhetősége és felhasználhatósága is javul. Ez kiegészülhet külső forrásokból származó ismeretanyaggal, aminek szövegszerü átmásolása helyett ezek forrásai hivatkozhatók, így elkerülhető, hogy egy nem naprakész információ „bent ragad” a folyamatdokumentációban. Egyidejüleg a szolgáltatás fenntartásához is kevesebb erőfeszítés lehet szükséges. Végső soron pedig a szervezeti egységen belül kialakult gyakorlatok is beépíthetőek, ezek elkülönülten kezelhetők a formális ismeretanyagtól (akár jelzőlámpaszerüen jelezve a kívánatos, illetve a kerülendő gyakorlatokat).

A személyi állomány változása jelentette kihívásra adott válaszként a tudástár a tapasztaltabb munkatársak betanítással kapcsolatos erőfeszítéseit egészítheti ki, ha az újonnan belépő munkatárs saját maga akár többször is tanulmányozhatja, visszakeresheti a munkájához szükséges ismeretanyagot. Fontos ezen felül, hogy a tapasztaltabb munkatársak ismeretanyagának dokumentálása pozitív visszajelzés lehet az érintettek felé is, hiszen tudásuk ilyen módon, „követendő példaként" jelenik meg mindenki felé, mely akár megtartóerő is lehet a szervezet szempontjából. A szervezeti egységen belül rendelkezésre álló, tudástárban rendszerett ismeretanyag organikus bővülésével, időről időre történő revíziójával hosszú távon kiegyenlíthetők a különböző formális képzési háttérből adódó különbségek. A szolgáltatás egyben eszköz lehet az egységes, igényes szervezeti egységen belüli szakszóhasználat kialakításához is.

A tudástár kialakításakor a takarékosság elvét is figyelembe kell venni, amennyiben egy már létező eszköz kerüljön adaptálásra. Ezek egy része azonban eszközbeszerzés lebonyolítását, illetve licenszdíj megfizetését igényelheti, ami nem fér össze a takarékosság elvárásával és hosszú távon akár pazarláshoz is vezethet. A választott eszközzel kapcsolatban felmerülő biztonsági elvárások teljesítése mellett emiatt a szolgáltatáshoz olyan eszköz kell, amelynek rendelkezésre állásához nem szükséges licenszdíj fizetése, és üzemeltetése, fenntartása is intézeti belső erőforrásokkal legyen megoldható.

Az eszköz segítségével hatékonyabban használhatók a betanításra fordítható természetbeni erőforrások is, ha a tapasztaltabb munkatársak által újra és újra leadott felkészítő előadások helyett az ismereteket előre, rendszerezve bocsátjuk rendelkezésre, majd a tréning a felmerült kérdésekre fókuszálva megy végbe. Ez az előny azonban csak akkor aknázható ki, ha a repozitóriumot a potenciális felhasználók köre ténylegesen használja is, amihez viszont a megfelelő felhasználói élményt kiemelten kell kezelni.

\section{EREDMÉNYEK}

A Technológia-értékelő Főosztály számára kifejlesztett tudásmenedzsmentet támogató eszköz, a Tudástár bemutatását specifikációjának, vagyis funkciójának, tartalmának és technikai működésének leírásán keresztül teszem meg.

\section{Funkcionális specifikáció}

A Tudástár alapvető funkciója, hogy egyirányú kommunikációs csatornaként közvetítsen a munkavégzéshez szükséges szakmai tartalmakat egy szervezeti egység munkatársai felé, és az előállított információmennyiség strukturáltan, illetve kereshető módon álljon rendelkezésre. A közvetített tartalomnak ugyanakkor megfelelő jogosultságkezelés mellett módosíthatónak kell lennie. A repozitórium szerkesztésének az irodai munkavégzéshez szükséges alapvető technikai (szövegszerkesztési, szoftverüzemeltetési) ismeretekkel megoldhatónak kell lennie. A Tudástárhoz való hozzáféréshez a VPN-en keresztül történő kapcsolódáson túl nem szükséges egyéb jogosultság, ugyanakkor a szerkesztéséhez adminisztrátori (tartalomkezelői) jogosultság szükséges. A tartalomkezelői jogosultság révén biztosítható a megjelenő tartalom feletti minőségi kontroll is.

\section{Tartalmi specifikáció}

A Tudástár tartalma formalizált, publikusan, de fragmentáltan rendelkezésre álló információkból, illetve informális, de szakmailag megalapozott, jó gyakorlatokból áll össze. A szakmai törzsanyag kézikönyvszerüen, a technológia-értékelői szakvélemény struktúráját leképező módon épül fel (orvosszakmai értékelés, egészség-gazdaságtani értékelés, költségvetési hatás értékelése, nemzetközi kitekintés, illetve ezek alfejezetei), ez egészül ki jó gyakorlatok dokumentációjával (esettanulmányok), eseti jelleggel készített szakirodalmi szemlével (szemle), illetve egyéb, támogató jellegű oldalakkal.

A tartalomgyártás során lényeges, hogy amennyiben már elkészített képzési anyag áll rendelkezésre, úgy annak történjen meg a feldolgozása, újrahasznosítása. Ezen felül a Tudástár által kínált többletfunkciók (kereshetőség, struktúráltság, egységes megjelenés) kihasználása érdekében a tartalmat nem letölthető fájlok, hanem a tartalomkezelő rendszerben rögzített dokumentáció formájában ésszerü rögzíteni.

\section{Technikai specifikáció}

A szolgáltatáshoz választott technikai megoldásnak jól skálázhatónak, a tartalomkezelésnek intuitívnak kell lennie. A legjobb felhasználói élmény és a legkiterjedtebb felhasz- 
nálás érdekében a szolgáltatásnak a szervezeti egység munkatársai számára attraktívnak és platformfüggetlennek, a szervezet számára pedig licenszdíjaktól mentes, forrásbevonás nélkül beszerezhetőnek és üzemeltethetőnek kell lennie.

A szolgáltatás müködtetéséhez a Grav tartalomkezelő rendszerre [1] esett a választás, tekintettel arra, hogy az a fenti kritériumoknak maradéktalanul megfelel. Így a fejlesztés egy már létező technikai megoldást adaptál. A közigazgatáson belül létező eddigi, tudásmegosztásra irányuló szolgáltatások (például az intézeten belüli Intranet) inkább a közigazgatási működéshez kapcsolódó tájékoztató ismeretanyagot közvetítettek, és egy-egy horizontális szervezeti egységhez kapcsolva müködtek.

\section{ÖSSZEGZÉS}

Egy hasonló, tudásmenedzsmentet támogató eszköz működése nem választható el annak a szervezetnek a céljaitól, amit kiszolgálni hivatott. Az „Együtt alakítjuk a jövőnket!” című, az Országos Gyógyszerészeti és Élelmezés-egészségügyi Intézet stratégiáját bemutató dokumentumban [2] lefektetettek alapján a tudástár számos szervezeti célhoz kapcsolódik, illetve közvetlenül valósítja meg az azok eléréséhez szükséges lépéseket.

A kiemelkedő szakmai tudás célkitűzéséhez a Technológia-értékelő Főosztály számára kifejlesztett Tudástár okos kapacitásbővítéssel járul hozzá, vagyis az új munkatársak felvételének segítésén túl folyamatos képzési színteret biztosít, a szervezeti egységen belüli tudást szétteríti és így a már meglévő erőforrásokat optimalizálja. A szolgáltatás megfelelő platform lehet az ismeretanyagot érintő kompe- tenciák vagy az esetleges hiányosságok körülírására, így segítve a képzési igények megfogalmazását a minőségbiztosítást szem előtt tartva. A tudástárat a szervezet gazdálkodási céljainak szempontjából vizsgálva elmondható, hogy a szolgáltatás egy olyan korszerű digitális megoldás, ami a jobb informatikai támogatás lévén javíthatja a munkavégzés hatékonyságát és egyes esetekben humánerőforrást szabadít fel, valamint a papírmentesség irányába is hat. Az utóbbiak különösen lényegesek az otthoni munkavégzés perspektívájából.

A hasonló digitális szolgáltatások esetén kulcskérdés a fenntarthatóság vizsgálata. Habár egy tudástár kiépítése munkaigényes, de a fenntartás alapesetben szervezeti belső forrásokból megoldható, azaz nem jelent további költséget. Hosszú távon, havonta körülbelül egy személynap szakmai vezetői és további egy személynap tartalomfejlesztői ráfordítást igényel. A szükséges informatikai támogatás mértéke félévente egy rendszergazdai személynap lehet. A fenntarthatóság ugyanakkor nem annyira anyagi, hanem elsősorban vezetői, másodsorban pedig munkatársi elköteleződés (jelen esetben felhasználás) függvénye. Egy hasonló repozitórium kiépítése és üzemeltetése nem egyszeri, hanem folyamatos feladatot jelent, hiszen a munkavégzéshez használt ismeretanyag vagy adatforrások is bővülnek, új jó gyakorlatok fejlődhetnek ki, de akár a szolgáltatás üzemeltetéséhez használt eszköz is maga továbbfejlődhet. A tartalom gondozása mellett a fenntarthatóság részéként el kell érni, hogy a munkatársak rendre a szolgáltatáshoz forduljanak, ha szakmai támogatásra van szükségük, melynek eszköze nem annyira az utasítás, mint inkább a magas szakmai színvonalú tartalom biztosítása.

\section{IRODALOMJEGYZÉK}

[1] Grav v1.7.18. Trilby Media. Elérhető: https://getgrav.org/ downloads [Utoljára elérve: 2021. 08. 26.]
[2] Országos Gyógyszerészeti és Élelmezés-egészségügyi Intézet: Együtt alakítjuk a jövőnket! Az OGYÉl 20202025-re tervezett stratégiája. Elérhető: https://www. ogyei.gov.hu/dynamic/strategia_2020_2025.pdf [Utoljára elérve: 2021. 08. 26.]

\section{A SZERZŐ BEMUTATÁSA}

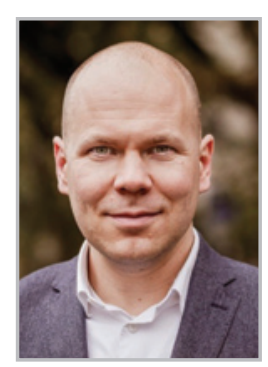

Merész Gergő diplomáit a Szegedi Tudományegyetem szociológia alapszakán (2009) és az Eötvös Loránd Tudományegyetem egészségpolitika tervezés és finanszírozás mesterszakán (2011) szerezte. Gyakornokként dolgozott a Healthware Tanácsadó Kft.- nél, valamint a Syreon Kutató Intézetnél, 2011 júliusától 2015 júliusáig a Syreon Kutató Intézet munkatársa, valamint az ELTE óraadó oktatója, 2015 augusztusától 2018 júliusáig a Semmelweis Egyetem Egészségügyi Menedzserképző központ munkatársa, 2018 júliusától az Országos Gyógyszerészeti és Élelmezés-egészségügyi Intézet Technológiaértékelő Főosztályának főosztályvezetője. 